\title{
Effects of reactive oxygen species on mitochondrial content and integrity of human anastomotic colorectal dehiscence: A preliminary DNA study
}

\author{
Lucia Potenza $\mathrm{PhD}^{1 *}$, Cinzia Calcabrini $\mathrm{PhD}^{1 *}$, Roberta De Bellis $\mathrm{BSc}^{1}$, Michele Guescini $\mathrm{PhD}^{1}$, \\ Umberto Mancini TECHN¹, Luigi Cucchiarini BSc${ }^{1}$, Gennaro Nappo MD², Rossana Alloni MD², \\ Roberto Coppola $\mathrm{MD}^{2}$, Laura Dugo $\mathrm{PhD}^{2}$, Marina Dachà DP2
}

L Potenza, C Calcabrini, R De Bellis, et al. Effects of reactive oxygen species on mitochondrial content and integrity of human anastomotic colorectal dehiscence: A preliminary DNA study. Can J Gastroenterol 2011;25(8):433-439.

BACKGROUND: Anastomotic dehiscence is one of the most severe complications of colorectal surgery. Gaining insight into the molecular mechanisms responsible for the development of anastomotic dehiscence following colorectal surgery is important for the reduction of postoperative complications.

OBJECTIVE: Based on the close relationship between surgical stress and oxidative stress, the present study aimed to determine whether a correlation exists between increased levels of reactive oxygen species and colorectal anastomotic dehiscence.

METHODS: Patients who underwent surgical resection for colorectal cancer were divided into three groups: patients with anastomotic dehiscence (group 1); patients without dehiscence who underwent neoadjuvant radiochemotherapy (group 2); and patients without anastomotic dehiscence who did not undergo neoadjuvant radiochemotherapy (group 3). Quantitative polymerase chain reaction and real-time polymerase chain reaction assays were performed to measure nuclear DNA and mitochondrial DNA (mtDNA) content, and possible oxidative damage to nonmalignant colon and rectal tissues adjacent to the anastomoses.

RESULTS: mtDNA content was reduced in the colon tissue of patients in groups 1 and 2. Rectal mtDNA was found to be more damaged than colonic mtDNAs in all groups. The 4977 bp common deletion was observed in the mtDNA of tissues from both the colon and rectum of all patients.

DISCUSSION: Patients in groups 1 and 2 were more similar to one another than to group 3, probably due to higher levels of reactive oxygen species in the mitochondria; the greater damage found in the rectum suggests that dehiscence originates primarily from the rectal area.

CONCLUSIONS: The present study of mtDNA analyses of normal human colon and rectal tissues from patients with colorectal cancer is among the first of its kind.

Key Words: Anastomotic dehiscence; Mitochondrial DNA; Oxidative DNA damage; Reactive oxygen species
Les effets des espèces oxygénées réactives sur le contenu mitochondrique et l'intégrité de la déhiscence colorectale anastomotique humaine : une étude d'ADN préliminaire

HISTORIQUE : La déhiscence anastomotique est l'une des pires complications de la chirurgie colorectale. Il est important d'en savoir plus sur les mécanismes moléculaires responsables de l'apparition de la déhiscence anastomotique après une chirurgie colorectale afin de réduire les complications postopératoires.

OBJECTIF : Compte tenu du lien étroit entre le stress chirurgical et le stress oxydatif, la présente étude visait à déterminer s'il existe une corrélation entre des taux accrus d'espèces oxygénées réactives et la déhiscence colorectale anastomotique.

MÉTHODOLOGIE : Les patients qui ont subi une résection chirurgicale en raison d'un cancer colorectal ont été séparés en trois groupes : les patients ayant une déhiscence anastomotique (groupe 1), les patients sans déhiscence qui ont subi une radiochimiothérapie néoadjuvante (groupe 2) et les patients sans déhiscence anastomotique qui n'ont pas subi de radiochimiothérapie néoadjuvante (groupe 3). Les chercheurs ont procédé à la réaction en chaîne de la polymérase quantitative et aux titrages de la réaction en chaîne de la polymérase en temps réel afin de mesurer le contenu d'ADN nucléaire et d'ADN mitochondrique (ADNmt) ainsi que les dommages oxydatifs éventuels au côlon et aux tissus rectaux non malins adjacents aux anastomoses. RÉSULTATS : Le contenu d'ADNmt était réduit dans les tissus du côlon des patients des groupes 1 et 2 . Les chercheurs ont constaté que, dans tous les groupes, l'ADNmt rectal était plus endommagé que l'ADN colique. Ils ont observé une délétion commune de 4977 paires de base dans les gènes des tissus du côlon et du rectum de tous les patients.

EXPOSÉ : Les patients des groupes 1 et 2 étaient plus similaires les uns aux autres qu'à ceux du groupe 3, probablement en raison de taux plus élevés d'espèces oxygénées réactives dans les mitochondries. Les dommages plus importants constatés dans le rectum indiquent que la déhiscence provient d'abord de la région rectale.

CONCLUSIONS : La présente étude des analyses d'ADNmt des tissus humains normaux du côlon et du rectum de patients ayant un cancer colorectal est l'une des premières du genre.
T is well known that surgical stress is closely related to oxidative stress, with consequent formation of molecules acting at the systemic level, modifying the main physiological activities of different tissues. Several studies have demonstrated that laparotomy and intestinal manipulation cause a temporary decrease of xanthine-oxidase enterocyte activity and catalase activity $(1,2)$. This phenomenon, associated with the uncoupling of mitochondrial oxidative phosphorylation, leads to superoxide and peroxide generation (3). Superoxide formed as a result of surgical stress can activate cytosolic and mitochondrial proteases in intestinal epithelial cells that stimulate lipid peroxidation and cascade damage primarily involving the membranes (4). Tissue repair mechanisms are negatively influenced by the presence of reactive oxygen species (ROS), which probably also contribute to colorectal anastomotic dehiscence. To date, however, very little is known about the molecular mechanisms underlying colorectal anastomotic dehiscence in humans.

Anastomotic dehiscence is one of the most severe complications of colorectal surgery, leading to infection, sepsis, and increased morbidity

\footnotetext{
${ }^{1}$ Dipartimento di Scienze Biomolecolari, Università degli Studi di Urbino "Carlo Bo", Urbino; ${ }^{2}$ Centro Integrato di Ricerche, Università Campus BioMedico, Rome, Italy. *Co-primary authors

Correspondence and reprints: Dr Lucia Potenza, Dipartimento di Scienze Biomolecolari, Via A. Saffi, 2 Università degli Studi di Urbino "Carlo Bo", 61029 Urbino, Italy. Telephone 39-0722-305232, fax 39-0722-305324, e-mail lucia.potenza@uniurb.it.

Received for publication March 22, 2010. Accepted January 28, 2011
} 
TABLE 1

Patient characteristics

\begin{tabular}{lccccc}
\hline Group & $\begin{array}{c}\text { Patients, } \\
\mathbf{n}\end{array}$ & Dehiscence & RT-CH & $\begin{array}{c}\text { Sex, } \\
\text { Male/female, } \mathbf{n}\end{array}$ & $\begin{array}{c}\text { Mean age, } \\
\text { years }\end{array}$ \\
\hline 1 & 8 & Yes & No & $6 / 2$ & 67.8 \\
2 & 10 & No & Yes & $5 / 5$ & 68.5 \\
3 & 16 & No & No & $6 / 10$ & 64.1 \\
\hline
\end{tabular}

RT-CH Neoadjuvant therapy

and mortality, and adversely affecting the length of hospitalization, costs and cancer recurrence. Notwithstanding the improvement in surgical techniques, the rate of anastomotic dehiscence remains high - from 3\% to $15 \%(5-9)$ - mainly occurring after rectal resection. Introduction of neoadjuvant chemotherapy and radiotherapy targeting the rectum and pelvis may be a factor that leads to an increase in anastomotic dehiscence. Many factors seem to play a pivotal role in the anastomosis healing process including suitable tissue perfusion, innovative anastomotic surgical techniques and the experience of the operating surgeon $(5,10,11)$. However, the pathogenesis and the causes of this phenomenon, which generally arises five to seven days after surgery, remain unclear. In recent years, scientists have shifted their focus from clinical or technical factors related to the process of tissue repair, to possible pathogenetic biochemical and/or ultrastructural mechanisms. For several years, collagen synthesis and related disorders have been considered to be important factors able to influence anastomosis strength (12-14). The hypothesis that collagen defects are linked to the development of anastomotic dehiscence is based on experimental evidence from patients in whom abdominal wall hernias are often associated with the presence of connective tissue disorders $(15,16)$. Similarly, it can be assumed that colorectal anastomotic dehiscence may be connected to a collagen metabolism defect such as a lowered collagen type I/III ratio or an increase in the expression of matrix metalloproteinases $(17,18)$ - a family of enzymes that degrade extracellular matrix components. In previous studies, it has been shown that the breaking strength of colonic anastomosis could be enhanced by substances that have increased collagen content such as a biosynthetic growth hormone (19-22), gentamicin (23) or matrix metalloproteinase inhibitors (24-27).

The present investigation focused on the relationship between increased levels of oxidative stress and colorectal anastomotic complications. The molecular mechanisms responsible for this phenomenon have yet to be investigated - the current study aimed to take the first step toward gaining a better understanding of such mechanisms.

Because ROS trigger the oxidation of macromolecules, such as proteins, lipids and nucleic acids, we evaluated their possible oxidative effects on mitochondrial DNA (mtDNA) and nuclear DNA (nDNA) in three groups of patients with colorectal cancer: those with anastomotic dehiscence; those without dehiscence who underwent neoadjuvant radiochemotherapy; and those without anastomotic dehiscence who did not undergo neoadjuvant radiochemotherapy.

Analyses were performed on normal human colon and rectal tissues that were sutured in colorectal anastomosis procedures performed on the previously mentioned patients. nDNA and mtDNA content and possible oxidative damage were analyzed by quantitative polymerase chain reaction (PCR) and real-time PCR.

Furthermore, radiotherapy induces oxidative stress that repair systems cannot efficiently counteract, thereby leading to a probable tendency toward anastomotic dehiscence. Many previous experimental trials in animals (28-31) - especially rats - evaluated oxidative stress levels in the colon; however, these investigations did not reproduce real human conditions with respect to radiotherapy doses nor with respect to surgical technique.

We also evaluated the association between tissue damage due to neoadjuvant treatments (ie, radiochemotherapy) and anastomotic outcome.

\section{METHODS}

\section{Patients}

Thirty-four patients with rectal cancer who underwent anterior rectal resection at the Hospital of University 'Campus Bio-Medico' of Rome (Italy) between 2006 and 2009 were selected. All patients provided written informed consent. The present study was performed in accordance with the Declaration of Helsinki (2000) of the World Medical Association, and was approved ethically by the Ethics Committee of University Campus Bio-Medico (reference number 03/08 protocol INT ComEt CBM).

Patients with connective tissue pathologies, microangiopathies, ulcerative colitis or Crohn's disease, or vasculitis were excluded.

Seventeen men and 17 women with a mean age of 68.2 years (range 48 to 93 years) were divided into three groups: those who did not undergo neoadjuvant therapy and developed dehiscence (group 1 $[n=8]$ ); those who received neoadjuvant therapy but did not develop dehiscence (group 2 [n=10]); and those who did not receive neoadjuvant therapy and did not develop dehiscence (group 3 [n=16]) (Table 1). Patients who received preoperative treatment were affected with lower rectal cancer (stage I or II); this treatment is routinely performed at the institution to improve postoperative outcome.

Neoadjuvant therapy consisted of variable and personalized chemotherapy, and a standard radiotherapy of 45 gray (Gy) fractionated as $180 \mathrm{cGy} /$ die directed to the rectum and lymph drainage, followed by $5.4 \mathrm{~Gy}$ (total dose) fractionated as $180 \mathrm{cGy} /$ die directed to the rectal lesion and to the mesorectum. The interval of time between radiotherapy and surgical resection was approximately one to two months. The experimental protocol was approved by the ethics committee.

\section{Isolation of total DNA}

Two tissue segments (one from the colon and one from the rectum) measuring $4 \mathrm{~mm} \times 5 \mathrm{~mm}$ were taken from the edges of the resected specimens. Total DNA was isolated using the QIAmp DNA mini kit (Qiagen, USA) according to the manufacturer's instructions. Total tissue DNA concentration was spectrophotometrically determined at $260 \mathrm{~nm}$ using a Beckman DU-640 spectrophotometer (Beckman, USA).

\section{Long PCR and quantitative PCR}

Long PCR was performed using a GeneAmp PCR System 9700 thermocycler (PE Applied Biosystems, USA). The reaction mixture contained $50 \mathrm{ng}$ or $100 \mathrm{ng}$ of total template DNA (to amplify mtDNA and nuclear DNA [nDNA], respectively), $2.5 \mu \mathrm{L}$ of $10 \times$ buffer, $200 \mu \mathrm{M}$ dNTPs, $0.5 \mu \mathrm{M}$ of each primer and $0.5 \mu \mathrm{L}$ of Advantage-2-polymerase (Clonotech, USA) in a final volume of $25 \mu \mathrm{L}$. Primers Af-Ar were used to amplify a $16.2 \mathrm{~kb}$ fragment of mtDNA, and primers $\mathrm{Bf}-\mathrm{Br}$ were used to amplify a $13.5 \mathrm{~kb}$ fragment of nDNA (Table 2). The PCR parameters are reported in Table 3 . The long PCR amplification products were electrophoresed on a $0.8 \%$ agarose Tris/Borate/EDTA gel, stained with ethidium bromide $(0.3 \mu \mathrm{g} / \mathrm{mL})$ and quantified by densitometric analysis of the intensity of bands using Quantity One software version 4.01 (Bio-Rad, USA).

\section{Detection of the mitochondrial $4977 \mathrm{bp}$ common deletion}

To assess the presence of the common deletion, which involves nucleotides from position 8470 to 13447 (accession number NC_001807.4), a pair of primers were used: F2 (Table 2) located at nucleotide position 8283 of the complete Homo sapiens mitochondrial sequence (accession number NC_001807.4) and R2 (Table 2) located at nucleotide position 13610 (NC_001807.4). These primers produce a 5347 bp amplicon from intact mtDNA and an amplicon of $370 \mathrm{bp}$ in the presence of a deletion (5347 to 4977) (Figure 1). PCR was performed in a final volume of $25 \mu \mathrm{L}$ containing $50 \mathrm{ng}$ of genomic DNA, $0.5 \mu \mathrm{M}$ of each of the above primers, $200 \mu \mathrm{M}$ dNTPs, $2.5 \mu \mathrm{L}$ of $10 \times$ buffer, $1.5 \mathrm{mM} \mathrm{MgCl}_{2}$ and 1.5 units of Taq DNA polymerase (Diatheva, Italy). Reaction conditions were as follows: denaturation at $95^{\circ} \mathrm{C}$ for $10 \mathrm{~min}$, followed by 30 cycles of $94^{\circ} \mathrm{C}$ for $30 \mathrm{~s}, 59^{\circ} \mathrm{C}$ for $30 \mathrm{~s}$ 
TABLE 2

Polymerase chain reaction primer pairs

\begin{tabular}{|c|c|}
\hline \multicolumn{2}{|c|}{$16.2 \mathrm{~kb}$ mitochondrial fragment } \\
\hline Af & 5'-TGAGGCCAAATATCATTCTGAG-3' \\
\hline Ar & 5'-TTTCATCATGCGGAGATGTTGG-3' \\
\hline \multicolumn{2}{|c|}{$13.5 \mathrm{~kb}$ nuclear fragment } \\
\hline$\overline{B f}$ & 5'-CGAGTAAGAGACCATTGTGGC-3' \\
\hline $\mathrm{Br}$ & 5'-GCACTGGCTTAGGAGTTGGAC-3' \\
\hline \multicolumn{2}{|c|}{$100 \mathrm{bp}$ mitochondrial fragment } \\
\hline ND1 $\mathrm{f}$ & 5'-ACGCCATAAAACTCTTCACCAAAG-3' \\
\hline ND1 $r$ & 5'-TAGTAGAAGAGCGATGGTGAGAGCTA-3' \\
\hline \multicolumn{2}{|c|}{$100 \mathrm{bp}$ mitochondrial fragment } \\
\hline ND4 $f$ & 5'-ССАТТСТССТССТАТСССТСААС-3' \\
\hline ND4 r & 5'-CACAATCTGATGTTTTGGGTTAAACTATATT-3' \\
\hline \multicolumn{2}{|c|}{$100 \mathrm{bp}$ nuclear fragment } \\
\hline$\overline{\beta-\operatorname{actin} f}$ & 5'-TGACTGGCCCGCTACCTCTT-3' \\
\hline$\beta$-actin $r$ & 5'-CGGCAGAAGAGAGAACCAGTGA-3' \\
\hline \multicolumn{2}{|c|}{$370 \mathrm{bp}$ mitochondrial fragment } \\
\hline$\overline{\mathrm{F} 2}$ & 5'-CCCСTCTAGAGCCCACTGTA-3' \\
\hline $\mathrm{R} 2$ & 5'-GAGTGCTATAGGCGCTTGTC-3' \\
\hline
\end{tabular}

f Forward; $r$ Reverse

TABLE 3

Thermal cycling parameters used in quantitative polymerase chain reaction

\begin{tabular}{lccc}
\hline & Cycle & Temperature, ${ }^{\circ} \mathbf{C}$ & Time \\
\hline $\begin{array}{l}16.2 \text { kb mitochondrial } \\
\text { fragment }\end{array}$ & $1 \times$ & 95 & $1 \mathrm{~min}$ \\
& $24 \times$ & 94 & $30 \mathrm{~s}$ \\
& $1 \times$ & 68 & $16 \mathrm{~min}$ \\
& $1 \times$ & 68 & $7 \mathrm{~min}$ \\
$13.5 \mathrm{~kb}$ nuclear fragment & & 4 & $\infty$ \\
& $1 \times$ & 95 & $1 \mathrm{~min}$ \\
& $30 \times$ & 94 & $30 \mathrm{~s}$ \\
& $1 \times$ & 68 & $13 \mathrm{~min}$ \\
& $1 \times$ & 68 & $12 \mathrm{~min}$ \\
\hline
\end{tabular}

and $72^{\circ} \mathrm{C}$ for $30 \mathrm{~s}$, with final extension at $72^{\circ} \mathrm{C}$ for $7 \mathrm{~min}$. The identities of the amplified products were confirmed by sequencing the products purified from the gel and comparing them with the appropriate mtDNA sequence (Figure 1).

\section{Real-time PCR}

Real-time PCR was performed to determine the ratio of mtDNA to nDNA, and to quantify ND4 lesions by amplifying both ND1 and ND4 (NADH dehydrogenase complex 1 and 4, respectively) as mtDNA and $\beta$-actin as nDNA. The first ratio was calculated as ND1/ $\beta$-actin and ND4/ $\beta$-actin. ND4 lesion frequency has been determined to correlate with the quantity of amplified ND1 and ND4. Real-time quantitative PCR (QPCR) was performed using an iCycler iQ MultiColor Real-time PCR Detection System (Bio-Rad, USA) and 2x Quantitect SYBR Green PCR kit (Qiagen, USA). The reaction mix (25 $\mu \mathrm{L}$ final volume) consisted of the following: $12.5 \mu \mathrm{L}$ Mix Hot-Start (Qiagen, USA), $50 \mathrm{ng} / \mu \mathrm{L}$ template DNA, $2 \mu \mathrm{L}$ SYBR Green and $0.3 \mu \mathrm{M}$ of each primer (Table 2). The PCR conditions were as follows: hot start at $95^{\circ} \mathrm{C}$ for $10 \mathrm{~min}$, followed by 40 cycles of the two steps at $95^{\circ} \mathrm{C}$ for $30 \mathrm{~s}$ and at $60^{\circ} \mathrm{C}$ for $30 \mathrm{~s}$. The threshold cycle was determined on the linear phase of PCRs using the iCycler iQ Optical System Software version 3 (BioRad, USA). The specificity of the amplification products was confirmed by examining thermal denaturation plots and by sample separation on a 3\% agarose gel. ND1 and

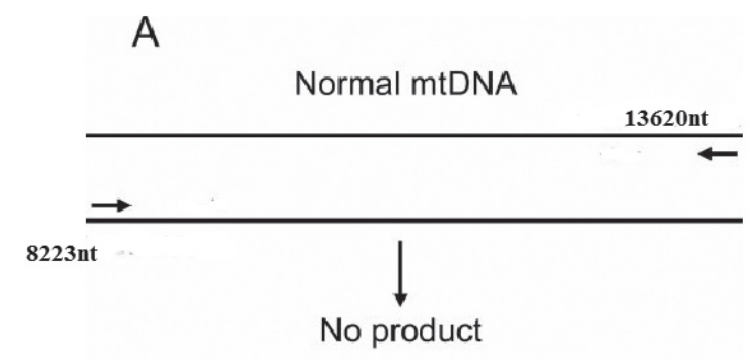

B

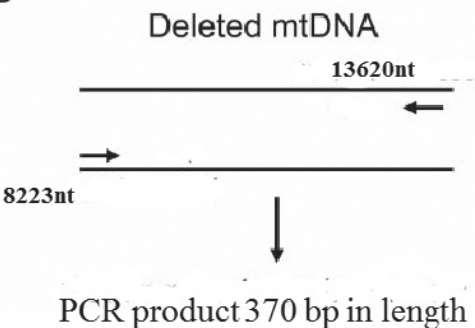

Figure 1) Polymerase chain reaction (PCR) to detect the presence of the 4977 bp common deletion. The primers amplify a fragment longer than $5 \mathrm{~kb}$ as indicated by the number (nucleotide position of the $5^{\prime}$ end of the primers) shown in the figure. A No PCR product generated in the absence of the deletion because the product was too long (ie, longer than $5 \mathrm{~kb}$ ) to be amplified during the selected elongation time (30 s). B In the presence of the deletion, a PCR product would be generated because the 4977 bp deletion brought the primers closer together, yielding a 370 bp product. mtDNA Mitochondrial DNA; nt Nucleotide

$\beta$-actin gene copy numbers were determined by interpolating the threshold cycle from standard curves, which were obtained using DNA from the human keratinocyte cell line NCTC 2544 (Figure 2). The ratios were obtained relating these mtDNA and nDNA quantities. Samples were tested in triplicate for each gene.

\section{Statistical analysis}

Statistical analysis was performed using Statistica version 6.1 (Statsoft, Italy). The variables among the groups were compared using a two-way ANOVA, and the Bonferroni test was used post hoc. Differences among the groups were considered to be statistically significant at $\mathrm{P}<0.05$, with a confidence level of $95 \%$.

\section{RESULTS}

Oxidative damage was evaluated in nDNA and mtDNA. Total genomic DNA was extracted from fragments of colon and rectum obtained from the margin of resected specimens, spectrophotometrically quantified and analyzed on an agarose gel to confirm its size and integrity (data not shown).

Two fragments of nDNA and mtDNA, corresponding to the long PCR products were quantified by densitometric analysis after gel electrophoresis (QPCR).

Polymerization activity of any thermostable polymerase is terminated in the presence of DNA lesions, such as strand breaks, abasic sites and some base modifications (eg, 8oxodA). Therefore, if DNA damage was severe, the high number of lesions on the template would induce a lower yield of amplification products (32).

The QPCR assay had already been established with these primers in the authors' laboratory $(33,34)$. The QPCR analyses of the two genomes showed that all three groups were not significantly different from one another, suggesting that oxidative damage in mtDNA (Figure $3 \mathrm{~A}$ ) or in nDNA was not extensive (Figure 3B). 


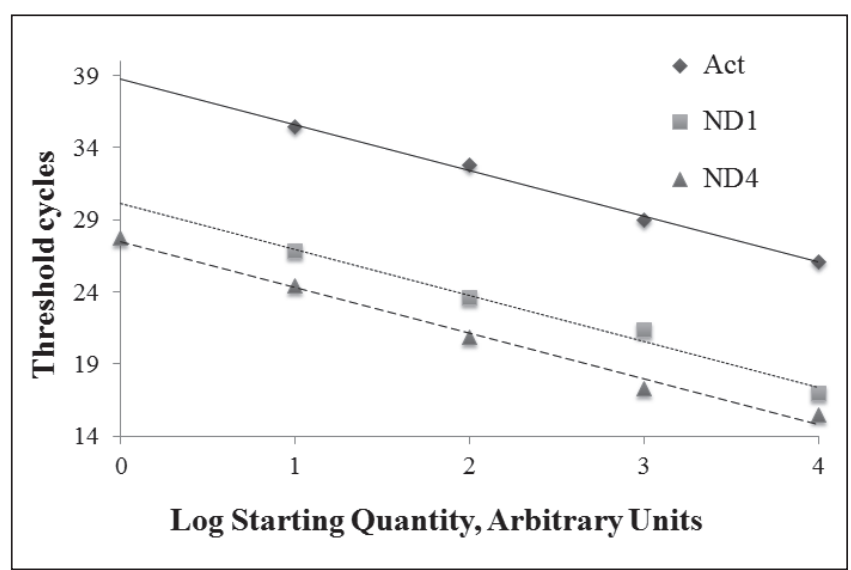

Figure 2) Standard curves of $\beta$-actin (Act), ND1 and ND4 amplification in real-time polymerase chain reaction (PCR) were obtained using DNA from the human keratinocyte cell line NCTC 2544. The efficiency of real-time PCR amplification was established from $100 \mathrm{ng}$ to $0.01 \mathrm{ng}$ (10-fold repeated dilutions) cellular DNA, which was allowed to react with primers specific to ND1, ND4 and $\beta$-actin genes. The standard curves and correlation coefficients were as follows: $y=-3.219 x+38.897, R^{2}=0.997$ $\left(\beta\right.$-actin) $; y=-3.198 x+26.959, R^{2}=0.984(N D 1) ; y=-3.177 x+27.482$, $R^{2}=0.994($ ND4)

To evaluate mtDNA content in colon and rectum tissues, real-time PCR of mitochondrial ND1 and ND4 genes normalized with the nuclear $\beta$-actin gene was performed. Results showed that there were no significant differences in either ND1/ $\beta$-actin or ND4/ $\beta$-actin ratios in the rectal tissue of all three groups of patients (Figure 4). In contrast, a statistically significant greater amount of mtDNA with ND1/ $\beta$-actin was found in the colon of group 3 patients than in the other two groups. ND4/ $\beta$-actin analysis showed no differences among the three groups, while it showed a significant difference between the colon and rectum of group 3 patients (Figure 4B). Differences between the ND4/ $\beta$-actin results and those of ND1/ $\beta$-actin led to the search for the $4977 \mathrm{bp}$ common deletion, which includes the ND4 gene. Therefore, PCR using primers F2-R2 that amplified a product of $370 \mathrm{bp}$ when the common deletion is present was performed. All patients were positive for this mutation (data not shown) both in rectal and colonic tissues; this evidence was confirmed and quantified by real-time QPCR reflected by the ND1/ND4 ratio. This final analysis (Figure 5) highlighted that rectal tissue was more damaged than colon tissue in each group, and that the differences were statistically significant.

\section{DISCUSSION}

Anastomotic dehiscence represents one of the most frequent complications of colorectal surgery. The introduction of important technical innovations (new suture threads, mechanic suturing apparatus and mini-invasive operating techniques) has improved standardization in anastomotic suture technique but has not provided a solution to the problem of anastomotic dehiscence. The present study aimed to find a possible correlation between dehiscence and increased levels of ROS, which has been investigated in animal model studies but not in humans. Therefore, we performed molecular analyses to detect and characterize potential ROS-associated DNA changes among patients classified in our three groups of patients (Table 1).

The level of oxidative damage in both the colon and rectum, which had been sutured to one another, was evaluated. Furthermore, for patients in group 2, we also investigated the possible effects of preoperative radiotherapy in both colon and rectum tissues, and whether significant oxidative damage was present in mtDNA and nDNA.

These two molecules have different susceptibilities to oxidative stress, probably due to different localization and structure: nDNA is a linear molecule present in the nucleus, while mtDNA is circular and located in the mitochondria.

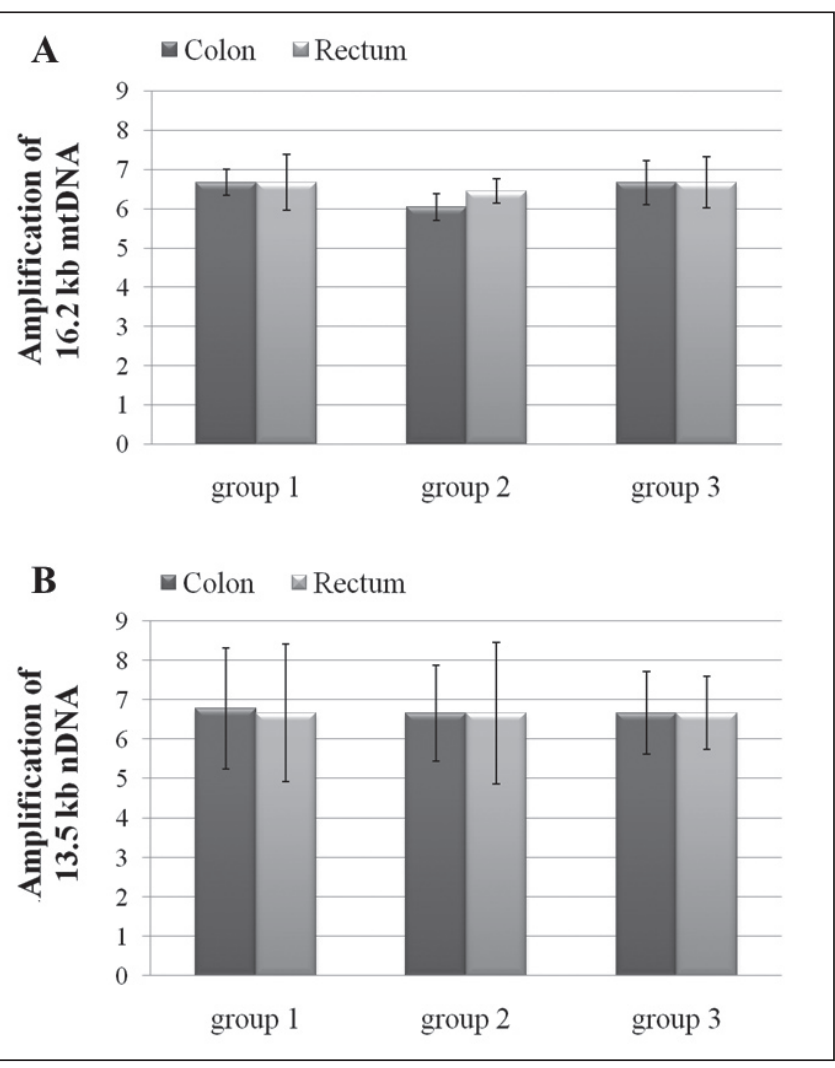

Figure 3) Densitometric analysis of the electrophoretic profiles of mitochondrial DNA (mtDNA) (A) and nuclear DNA (nDNA) (B) long polymerase chain reaction assays from colon and rectum DNA of the three groups. Data expressed as mean \pm SEM of all patients in each group; all samples were analyzed in triplicate. No significant differences were found among groups analyzed by ANOVA followed by an appropriate post hoc test

mtDNA is a double-stranded molecule 16,569 bp long, and was completely sequenced in 1981 (35). This gene encodes 13 polypeptides, all of which are essential in electron transport and ATP formation (36); it is 10 times more susceptible to insults than nDNA (37). This condition is easily attributable to various factors such as exposure to high levels of ROS produced during oxidative phosphorylation (38), the absence of histone protection and limited DNA repair systems (39); in the mitochondrion, a base excision repair system has been documented more extensively than the nucleotide excision repair system (40). Consequently, oxidative stress damage to mtDNA can lead to incorrect gene expression, with a consequent loss of membrane potential and a vicious circle input between ROS generation and mtDNA oxidation owing to the complete lack of ATP synthesis and, finally, cell death.

Recently, scientists have focused on the mitochondrion because of the various roles of this organelle including energy production, electron transport, cell motility, cell proliferation and apoptosis (41-43). Alteration of mitochondrial function has been discovered in many tumours $(44,45)$ as well as punctiform mutations or deletions in dislocation loops or in coding regions, and little deletion of mitochondrial DNA in tumours of the colon (46-48), breast (49), stomach (50), kidney (51), esophagus (52), thyroid (53), head and neck (54).

There is also evidence that mtDNA alterations can influence cell susceptibility to therapeutic cancer-fighting agents $(42,55)$. It has also been observed that altered mtDNA content, which is organ or tissue specific, can lead to a compensatory response to the decay of respiratory function (56).

Results obtained with QPCR did not show significant differences among the three groups of patients, suggesting that oxidative injury is 


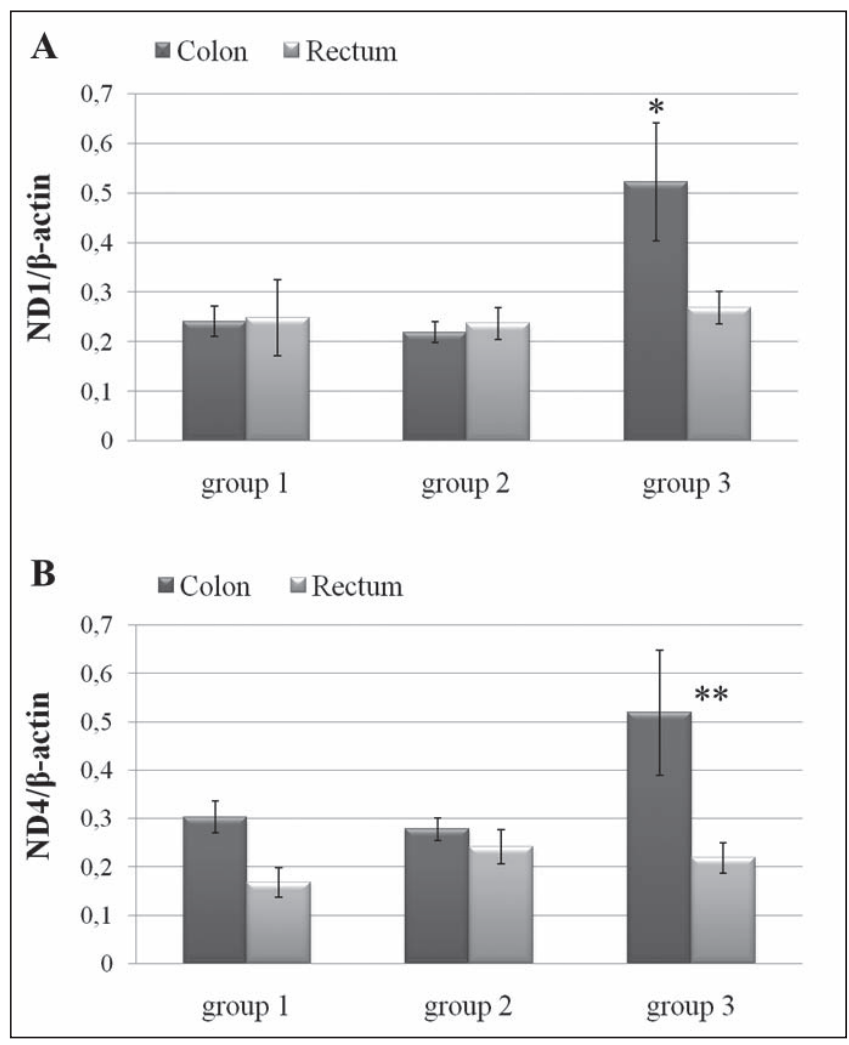

Figure 4) Determination of mitochondrial DNA/nuclear DNA ratio reflected by ND1/3-actin (A) and ND4/B-actin (B) using real-time polymerase chain reaction as described in the Methods section. Data expressed as mean \pm SEM of all patients in each group; all samples were analyzed in triplicate. Two-way ANOVA and Bonferroni-post hoc test were performed. $* P<0.05$ comparing group 3 colon DNA with group 2 or group 1 colon DNA; $* * P<0.01$ comparing group 3 colon DNA with group 3 rectum DNA

not extensive enough at the DNA level to be detected by this technique. The design of additional assays are in progress in our laboratory to measure the level of 8 oxodG, an oxidized base that is formed by oxidative injury and not efficiently detected by QPCR because it does not significantly stall the progression of thermostable DNA polymerases.

\section{Results obtained by quantitative real-time PCR were more interesting}

Colon and rectum mtDNA content were evaluated by ND1/ $\beta$-actin and ND4/ $\beta$-actin ratios. These assays highlighted no differences in rectum samples among the three groups, or in neoadjuvant treated samples in which changes in rectum mtDNA content were expected. In contrast, the same assays of colon tissue revealed differences between group 3 and the other two groups, which proved to be more similar to one another. The significant reduction in colon mtDNA content in group 2 (Figure 4A) when compared with patients in group 3 could be attributable to chemotherapy; however, the reason for the reduction of mtDNA content in group 1 remains unclear. Because radiochemotherapy increases ROS production (28-31), the results of the present study may lend support to the initial hypothesis that, in patients with dehiscence, there should be a greater development of ROS inside the mitochondria.

The common deletion, which includes the ND4 gene, was found in all patients. To quantify this deletion, we performed experiments to evaluate the ND1/ND4 ratio. The rectum was shown to be more damaged than the colon in that ND1 was greater than ND4 (Figure 5). In particular, there were no significant differences in rectum analyses among the three groups of patients. The colons of patients in group 3,

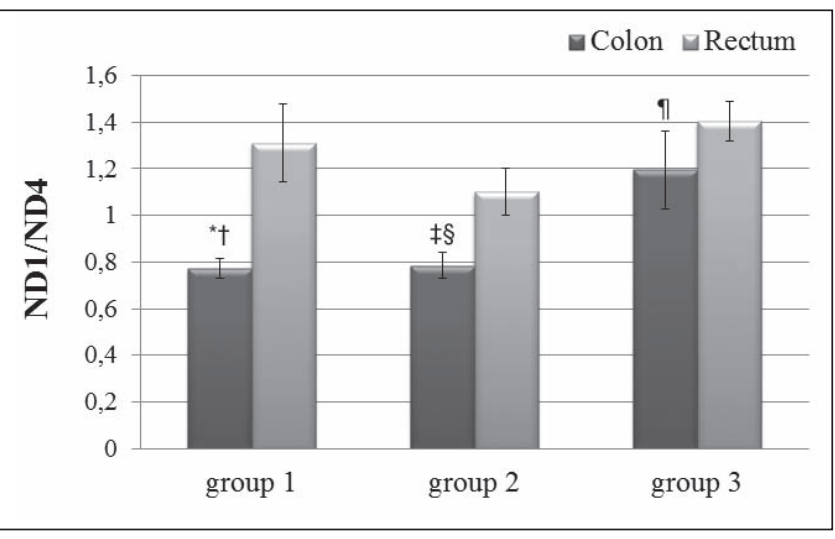

Figure 5) Determination of ND4 lesions reflected by ND1/ND4 ratio using real-time polymerase chain reaction as described in the Methods section. Data are presented as mean \pm SEM of all patients of each group; all samples were analyzed in triplicate. Two-way ANOVA and Bonferronipost hoc test were performed. $* P<0.01$ comparing group 1 colon DNA with group 3 colon DNA; ${ }^{\dagger} \mathrm{P}<0.001$ comparing group 1 colon DNA with group 1 rectum DNA; ${ }^{\mathrm{P}}<0.01$ comparing group 2 colon DNA with group 3 colon DNA; ${ }^{\S} P<0.01$ comparing group 2 colon DNA with group 2 rectum DNA; I $P<0.001$ comparing group 3 colon DNA with group 3 rectum DNA

however, were more damaged than the colons of patients in groups 1 and 2. We speculate that the greater content of mtDNA, found using $\mathrm{ND} 1 / \beta$-actin in this group, represents a compensatory response to the increased level of deletion observed in the same group.

This common deletion has been found in several tumours, stressed tissues, conditons of aging and even apparently normal tissues (57-63). In studies of thyroid tumours, Maximo et al (64) found that $100 \%$ of Hürtle adenoma and carcinoma cells carried the common deletion, and $0 \%$ to $33 \%$ of the adjacent parenchyma carried the same change. A high prevalence of this deletion (95\%) has also been found in esophageal tissue adjacent to tumour(s) in patients with esophageal squamous cell carcinoma of which no evidence was found in peripheral blood (65). In the present study, we found that $100 \%$ of the nonmalignant tissues carried the deletion. To establish whether this common deletion might represent a risk marker for colorectal tumours, further analysis of the deletion in subjects without cancer is required. This analysis will be assessed to determine whether the deletion can be directly associated with colorectal cancer or is simply an age- or exposure-related consequence.

Despite the small sample size examined in the present study, we offer the following conclusions: groups 1 and 2 were found to be more similar with one another than group 3, a finding that might support the initial hypothesis in which there is increased ROS production; the greater damage that we found in the rectum suggests that dehiscence may originate primarily from the rectal side; hence, future research should focus on this tissue using transcriptomic analyses to detect differentially expressed genes as possible markers of dehiscence.

\section{REFERENCES}

1. Anup R, Aparna V, Pulimood A, Balasubramanian KA.

Surgical stress and the small intestine: Role of oxygen free radicals. Surgery 1999;125:560-9.

2. Thomas S, Pulimood A, Balasubramanian KA. Heat preconditioning prevents oxidative stress-induced damage in the intestine and lung following surgical manipulation. Br J Surg 2003;90:473-81.

3. Anup R, Susuma P, Blasubramanian KA. Intestinal mitochondrial dysfunction in surgical stress. J Surg Res 2001;99:120-8.

4. Anup R, Blasubramanian KA. Protease, activation during surgical stress in the rat small intestine. J Surg Res 2000;92:283-90.

5. Alves A, Panis Y, Trancart D, et al. Factors associated with clinically significant anastomotic leakage after large bowel resection: Multivariate analysis of 707 patients. World J Surg 2002;26:499-502. 
6. Guenaga KK, Matos D, Wille-Jorgensen P. Mechanical bowel preparation for elective colorectal surgery. Cochrane Database Syst Rev 2009:CD001544.

7. Ptok H, Marusch F, Meyer F, et al. Impact of anastomotic leakage on oncological outcome after rectal cancer resection. Br J Surg 2007;94:1548-54

8. Schmidt O, Merkel S, Hohenberger W. Anastomotic leakage after low rectal stapler anastomosis: Significance of intraoperative anastomotic testing. Eur J Surg Oncol 2003;29:239-43.

9. Vignali A, Gianotti L, Braga M, et al. Altered microperfusion as the rectal stump is predictive for rectal anastomotic leak. Dis Colon Rectum 2000;43:76-82.

10. Kasperk R, Philipps B, Vahrmeyer M, Willis S, Schumpelick V. Risk factors for anastomosis dehiscence after very deep colorectal and coloanal anastomosis (in German with English abstract). Chirurg 2000;71:1365-69.

11. Kingham TP, Pachter HL. Colonic anastomotic leak: Risk factors, diagnosis, and treatment. J Am Coll Surg 2009;208:269-78.

12. Brasken P, Lehto M, Renvall S. Changes in the connective tissue composition of the submucosal layer of colonic anastomosis. Acta Chir Scand 1989;155:413-9.

13. Brasken P, Renvall S, Sandberg M. Fibronectin and collagen expression in healing experimental colonic anastomosis. Br J Surg 1991;78:1048-52.

14. Jiborn H, Ahonen J, Zederfeldt B. Healing of experimental colonic anastomosis. Effect of suture technique on collagen metabolism in the colonic wall. Am J Surg 1980;139:406-13.

15. Klinge U, Zheng H, Si Z, et al. Expression of the extracellular matrix proteins collagen I, collagen III and fibronectin anc matrix metalloproteinase- 1 and -13 in the skin of patients with inguinal hernia. Eur Surg Res 1999;30:480-5.

16. Klinge U, Si Z, Zheng H, Bhardwaj RS, Klosterhalfen B. Abnormal collagen I and III distribution in the skin of patients with incisional hernia. Eur Surg Res 2000;32:43-7.

17. Onodera H, Ikeuchi D, Nagayama S, Imamura M. Weakness of anastomotic site in diabetic rats is caused by changes in the integrity of newly formed collagen. Dig Surg 2004;21:146-51.

18. Stumpf M, Klinge U, Wilms A, et al. Changes of the extracellular matrix as a risk factor for anastomotic leakage after large bowel surgery. Surgery 2005;137:229-34.

19. Christensen H, Oxlund H, Laurberg S. Postoperative biosynthetic human growth hormone increases the strength and collagen deposition of experimental colonic anastomoses. Int J Colorectal Dis 1991;6:133-8

20. Christensen H, Flyvbjerg A. Dose-dependent stimulatory effect of human growth hormone on the strength and collagen deposition of colonic anastomoses in the rat. Acta Endocrinol (Copenhagen) 1992;126:438-43.

21. Christensen $\mathrm{H}$, Oxlund $\mathrm{H}$. Growth hormone increases the collagen deposition rate and breaking strength of left colonic anastomoses in rats. Surgery 1994;116:550-6.

22. Tei TM, Kissmeyer-Nielsen P, Flyvbjerg A, Christensen H. Growth hormone is a stimulating but not an essential factor in healing of colon. A study in GH-deficient dwarf rats. Scand J Surg 2006;95:205-10.

23. Binnebosel M, Junge K, Kaemmer DA, et al. Intraperitoneally applied gentamicin increases collagen content and mechanical stability of colon anastomosis in rats. Int J Colorectal Dis 2009;24:433-40.

24. Agren MS, Andersen TL, Mirastschijski U, et al. Action of matrix metalloproteinases at restricted sites in colon anastomosis repair: An immunohistochemical and biochemical study. Surgery 2006;140:72-82.

25. Komen N, de Bruin RW, Kleinrensink GJ, Jeekel J, Lange JF. Anastomotic leakage, the search for a reliable biomarker. A review of the literature. Colorectal Dis 2008;10:109-15.

26. Pasternak B, Rehn M, Andersen L, et al. Doxycycline-coated sutures improve mechanical strength of intestinal anastomoses. Int J Colorectal Dis 2008;23:271-6.

27. Syk I, Agren MS, Adawi D, Jeppsson B. Inhibition of matrix metalloproteinases enhances breaking strength of colonic anastomoses in an experimental model. Br J Surg 2001;88:228-34.

28. Bedirli A, Kerem M, Karahacioglu E, et al. Effects of two conventional preoperative radiation schedules on anastomotic healing in the rat colon. Eur Surg Res 2007;39:141-7.
29. Karliczek A, Zeebregts CJ, Benaron DA, et al. Preoperative irradiation with $5 \times 5$ Gy in a murine isolated colon loop model does not cause anastomotic weakening after colon resection. Int J Colorectal Dis 2008;23:1115-24.

30. Kuzu MA, Koksoy C, Akyol FH, Uzal D, Kale IT. Colonic anastomotic healing after preoperative chemo-radiotherapy in rat. Radiat Med 1999;17:181-7.

31. Kerem M, Bedirli A, Karahacioglu E, et al. Effects of soluble fiber on matrix metalloproteinase-2 activity and healing of colon anastomosis in rats given radiotherapy. Clin Nutr 2006;25:661-70.

32. Santos JH, Mandavilli BS, Van HB. Measuring oxidative mtDNA damage and repair using quantitative PCR. Methods Mol Biol 2002;197:159-76.

33. Guidi C, Potenza L, Sestili P, et al. Differential effect of creatine on oxidatively-injured mitochondrial and nuclear DNA. Biochim Biophys Acta 2008;1780:16-26.

34. Potenza L, Calcabrini C, De Bellis R, et al. Effect of quercetin on oxidative nuclear and mitochondrial DNA damage. Biofactors 2008;33:33-48.

35. Anderson S, Bankier AT, Barrell BG, et al. Sequence and organization of the human mitochondrial genome. Nature 1981;290:457-65.

36. Brown WM, Prager EM, Wang A, Wilson AC. Mitochondrial DNA sequences of primates: Tempo and mode of evolution. J Mol Evol 1982;18:225-39.

37. Yakes FM, Van HB. Mitochondrial DNA damage is more extensive and persists longer than nuclear DNA damage in human cells following oxidative stress. Proc Natl Acad Sci U S A 1997;94:514-9.

38. Adam W, Hartung J, Okamoto H, Saha-Moller CR, Spehar K. $\mathrm{N}$-hydroxy-4-(4-chlorophenyl)thiazole-2(3H)-thione as a photochemical hydroxyl-radical source: photochemistry and oxidative damage of DNA (strand breaks) and 2'-deoxyguanosine (8-oxodG formation). Photochem Photobiol 2000;72:619-24.

39. Godley BF, Shamsi FA, Liang FQ, et al. Blue light induces mitochondrial DNA damage and free radical production in epithelial cells. J Biol Chem 2005;280:21061-6.

40. Makrigiorgos GM, Bump E, Huang C, Baranowska-Kortylewicz J, Kassis AI. A fluorimetric method for the detection of coppermediated hydroxyl free radicals in the immediate proximity of DNA. Free Radic Biol Med 1995;18:669-78.

41. Schatz G. Mitochondria: Beyond oxidative phosphorylation. Biochim Biophys Acta 1995;1271:123-6.

42. Singh KK, Russell J, Sigala B, et al. Mitochondrial DNA determines the cellular response to cancer therapeutic agents. Oncogene 1999;18:6641-6.

43. Wallace KB, Eells JT, Madeira VM, Cortopassi G, Jones DP. Mitochondria-mediated cell injury. Symposium overview. Fundam Appl Toxicol 1997;38:23-37.

44. Pedersen PL. Mitochondrial events in the life and death of animal cells: A brief overview. J Bioenerg Biomembr 1999;31:291-304.

45. Rempel A, Mathupala SP, Griffin CA, Hawkins AL, Pedersen PL. Glucose catabolism in cancer cells: Amplification of the gene encoding type II hexokinase. Cancer Res 1996;56:2468-71.

46. Akouchekian M, Houshmand M, Hemati S, Ansaripour M, Shafa M. High rate of mutation in mitochondrial DNA displacement loop region in human colorectal cancer. Dis Colon Rectum 2009;52:526-30.

47. Habano W, Sugai T, Yoshida T, Nakamura S. Mitochondrial gene mutation, but not large-scale deletion, is a feature of colorectal carcinomas with mitochondrial microsatellite instability. Int J Cancer 1999;83:625-629.

48. Polyak K, Li Y, Zhu H, et al. Somatic mutations of the mitochondrial genome in human colorectal tumours. Nat Genet 1998;20:291-3.

49. Richard SM, Bailliet G, Paez GL, et al. Nuclear and mitochondrial genome instability in human breast cancer. Cancer Res 2000;60:4231-7.

50. Burgart LJ, Zheng J, Shu Q, Strickler JG, Shibata D. Somatic mitochondrial mutation in gastric cancer. Am J Pathol 1995;147:1105-11.

51. Welter C, Kovacs G, Seitz G, Blin N. Alteration of mitochondrial DNA in human oncocytomas. Genes Chromosomes Cancer 1989;1:79-82.

52. Kumimoto H, Yamane Y, Nishimoto Y, et al. Frequent somatic mutations of mitochondrial DNA in esophageal squamous cell carcinoma. Int J Cancer 2004;108:228-231.

53. Tong BC, Ha PK, Dhir K, et al. Mitochondrial DNA alterations in thyroid cancer. J Surg Oncol 2003;82:170-3. 
54. Fliss MS, Usadel H, Caballero OL, et al. Facile detection of mitochondrial DNA mutations in tumors and bodily fluids. Science 2000;287:2017-2019.

55. Liang BC, Ullyatt E. Increased sensitivity to cis-diamminedichloroplatinum induced apoptosis with mitochondrial DNA depletion. Cell Death Differ 1998;5:694-701.

56. Barrientos A, Casademont J, Cardellach F et al. Reduced steady-state levels of mitochondrial RNA and increased mitochondrial DNA amount in human brain with aging. Brain Res Mol Brain Res 1997:52:284-9.

57. Cortopassi GA, Arnheim N. Detection of a specific mitochondrial DNA deletion in tissues of older humans. Nucleic Acids Res 1990;18:6927-33.

58. Fukushima S, Honda K, Awane M, et al. The frequency of 4977 base pair deletion of mitochondrial DNA in various types of liver disease and in normal liver. Hepatology 1995;21:1547-51.

59. Hsieh RH, Hou JH, Hsu HS, Wei YH. Age-dependent respiratory function decline and DNA deletions in human muscle mitochondria. Biochem Mol Biol Int 1994:32:1009-22.

60. Lee HC, Pang CY, Hsu HS, Wei YH. Differential accumulations of 4,977 bp deletion in mitochondrial DNA of various tissues in human ageing. Biochim Biophys Acta 1994;1226:37-43.
61. Lezza AM, Boffoli D, Scacco S, Cantatore P, Gadaleta MN. Correlation between mitochondrial DNA 4977-bp deletion and respiratory chain enzyme activities in aging human skeletal muscles. Biochem Biophys Res Commun 1994;205:772-9.

62. Maximo V, Soares P, Seruca R, et al. Microsatellite instability, mitochondrial DNA large deletions, and mitochondrial DNA mutations in gastric carcinoma. Genes Chromosomes Cancer 2001;32:136-43.

63. Simonetti S, Chen X, DiMauro S, Schon EA. Accumulation of deletions in human mitochondrial DNA during normal aging: Analysis by quantitative PCR. Biochim Biophys Acta 1992;1180:113-22.

64. Maximo V, Soares P, Lima J, Cameselle-Teijeiro J, Sobrinho-Simoes M. Mitochondrial DNA somatic mutations (point mutations and large deletions) and mitochondrial DNA variants in human thyroid pathology: A study with emphasis on Hurthle cell tumors. Am J Pathol 2002;160:1857-65.

65. Abnet CC, Huppi K, Carrera A, et al. Control region mutations and the 'common deletion' are frequent in the mitochondrial DNA of patients with esophageal squamous cell carcinoma. BMC Cancer 2004;4:30. 


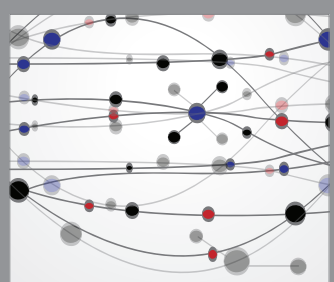

The Scientific World Journal
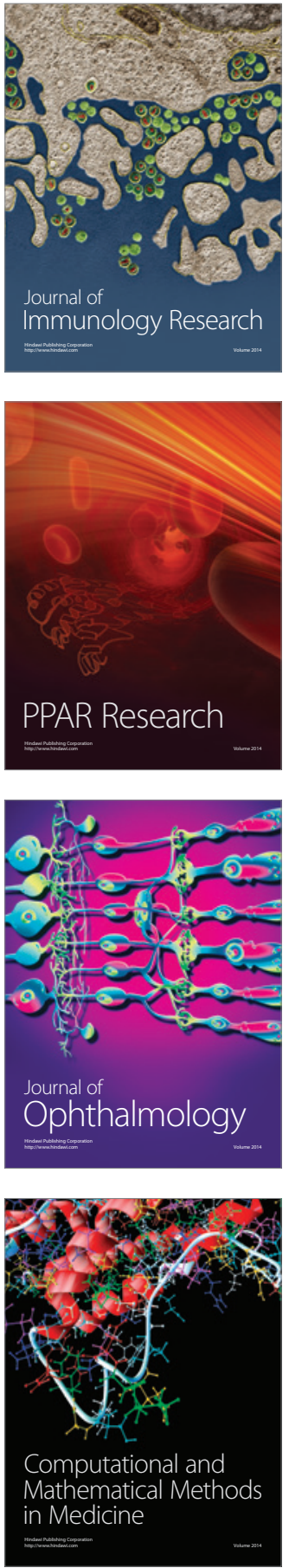

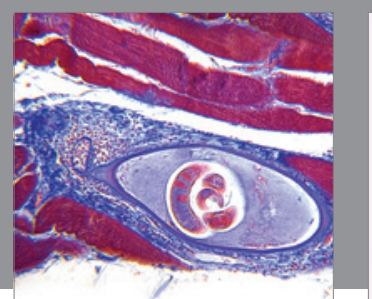

Gastroenterology Research and Practice

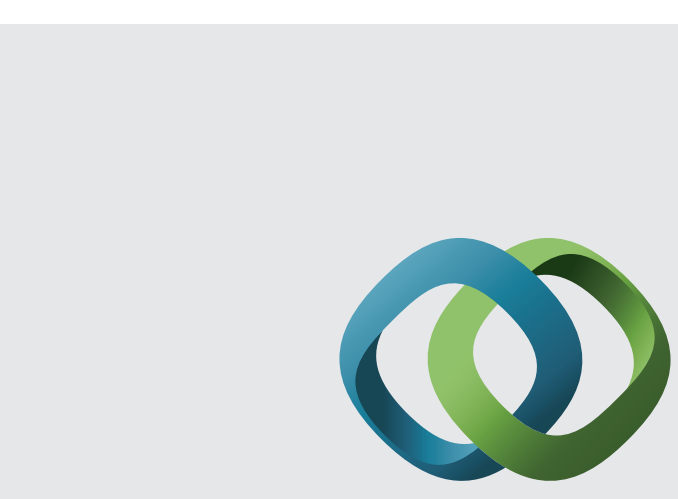

\section{Hindawi}

Submit your manuscripts at

http://www.hindawi.com
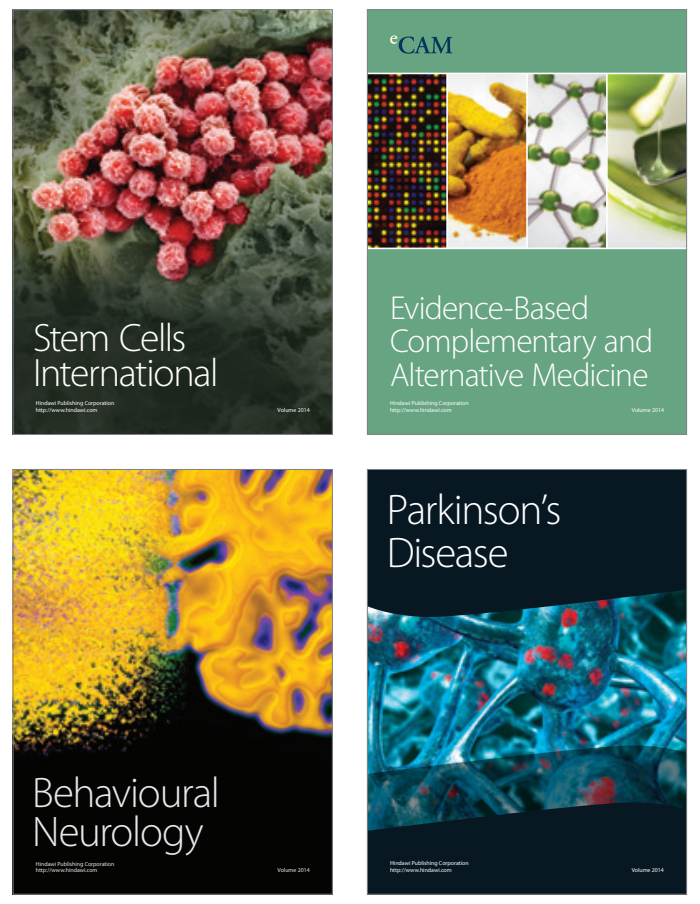
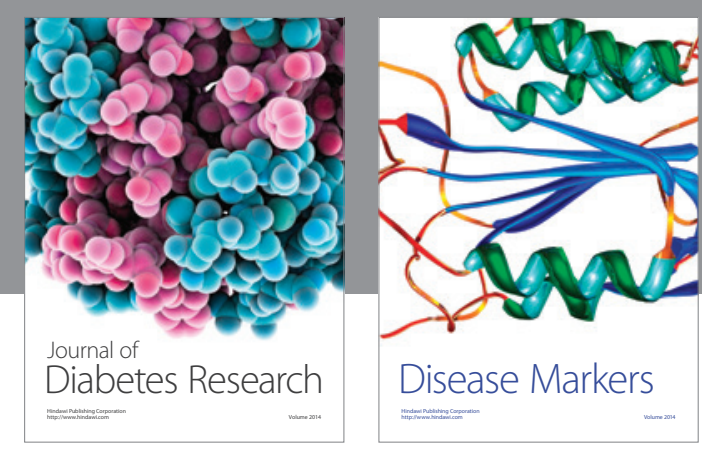

Disease Markers
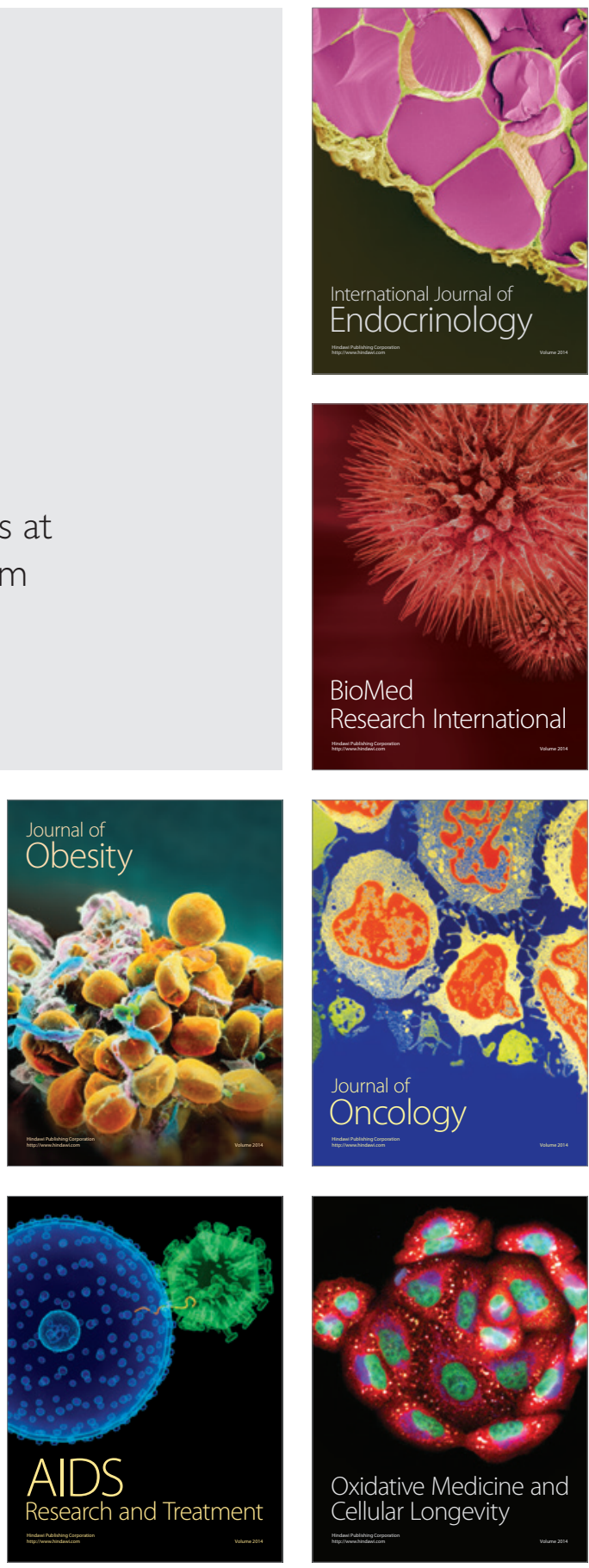